\title{
楆
}

\section{The problem of theodicy and the theology of the cross}

\author{
Nico Vorster \\ School for Ecclesiastical Sciences \\ Potchefstroom Campus \\ North-West University \\ POTCHEFSTROOM \\ E-mail: nvorster@telkomsa.net
}

\section{Abstract \\ The problem of theodicy and the theology of the cross}

Theodicy is the attempt to justify God's righteousness and goodness amidst the experience of evil and suffering in the world. This article discusses Karl Barth's Christological and Jürgen Moltmann's eschatological approach to the problem of theodicy. The central theoretical argument is that the problem of theodicy poses a major hermeneutical challenge to Christianity that needs to be addressed, since it has implications for the way in which theology defines itself. Questions that arise are: What are the boundaries of theology? What are the grounds on which the question of theodicy must be asked? Is the Christian understanding of God's omnipotence truly Scriptural? The modern formulation of theodicy finds its origin in the Enlightenment that approaches the problem from a theoretical framework based on human experience. This theoretical approach leads, however, to further logical inconsistencies. Theology must rather approach the problem in the same way as Scripture does, by taking the cross, resurrection and parousia of Christ as point of departure. The cross and resurrection are a sign that suffering is not part of God's plan and at the same time an affirmation of God's victory over suffering and evil.

Opsomming

\section{Die teodisee-probleem en kruisteologie}

Die teodisee-probleem handel oor die vraag hoe die realiteit van boosheid en lyding versoen kan word met die almag en liefde van God. As God nie boosheid kan verhoed nie, is Hy nie almagtig nie. As Hy kan, is Hy nie liefdevol nie, want die realiteit word deur boosheid en lyding gekenmerk. Hierdie artikel 
behandel die Christologiese benadering van Karl Barth en die eskatologiese benadering van Jürgen Moltmann tot die teodisee-vraag. Die sentraal-teoretiese argument is dat die teodisee-vraag 'n hermeneutiese uitdaging aan die Christelike teologie rig. Die vraag is: Wat is die gronde waarop teologie hierdie vraag moet antwoord? Wat is die grense van teologie? Is die klassieke Christelike verstaan van God se almag, werklik Skriftuurlik, of is dit nie dalk meer beïnvloed deur GrieksRomeinse godsbeelde nie? Die teodisee-vraag, in sy huidige vorm, is binne die Verligting geformuleer, en word gevolglik deur 'n rasionalistiese benadering gekenmerk. Die Christelike teologie moet egter nie die teodisee-vraag op dieselfde wyse benader as ateïsme en teïsme nie, omdat 'n teoretiese benadering wat die probleem vanuit die menslike ervaring benader net tot logiese teenstrydighede lei. Die teologie moet die vraagstuk eerder op dieselfde wyse as die Skrif benader, deur die kruis en opstanding van Christus as uitgangspunt te neem. Die kruis en opstanding van Chrstus is enersyds 'n teken dat lyding en boosheid nie deel van die goddelike plan is nie, en andersyds 'n bevestiging dat God lyding en boosheid oorwin.

\section{Introduction}

Theodicy (theo-dike) is the attempt to justify God's righteousness and goodness amidst the experience of evil and suffering in the world. In essence it asks questions about the unique identity and attributes of God, specifically the relation between God's omnipotence, goodness and love. The problem that theodicy states, is a logical problem: If God cannot abolish the world's evil, He is not omnipotent. If He can abolish evil, $\mathrm{He}$ is not a good and loving God, because evil exists.

Though the problem of theodicy was addressed in various ways throughout history, it became exceedingly prominent in the world after Auschwitz. Auschwitz confronted humanity with the horror of evil as never seen before. Simplistic theological explanatians of the origin of evil and the relation between evil and an omnipotent, loving God would no longer suffice. The Holocaust and Auschwitz led to the rise of what Moltmann (1974:221) calls protest atheism. For many people the horrors of the Holocaust are evidence that God does not exist, because a loving and omnipotent God would not allow such suffering and cruelty. In fact, the problem of theodicy is one of the driving forces behind the rapid secularisation of the postwar Western civilisation. 
The horrors of the Holocaust gave rise to a new theological movement in the 1950s and 1960s that attempted to come to terms with evil and suffering by focusing on a theologia crucis. Karl Barth can be considered as the founding father of this theological movement. He emphasised, over and against liberal theology, the central importance of the event of the cross as the defining moment in history that joins history and eternity together. Barth saw the theology of the cross as God coming to us by identifying Himself with our suffering, and being for us both in action and word (cf. Louw, 2000:81). His theology of the cross influenced Jürgen Moltmann's development of an eschatologia crucis. According to Moltmann suffering is not part of God's divine purpose. Innocent suffering cannot be explained, nor justified. However, the resurrection of Christ provides the hope that God will conquer over all evil and suffering (cf. Bauckham, 1989:300).

This article will discuss the significance of Karl Barth's and Jürgen Moltmann's theology of the cross for the problem of theodicy. At the end of the article an attempt will be made to give certain guidelines that can stimulate the ongoing discussion on theodicy. The central theoretical argument of this article is that the problem of theodicy poses a major hermeneutical challenge to Christianity that needs to be addressed, since it has implications for the way in which theology define itself.

\section{Karl Barth}

\subsection{Christocentric theodicy}

Karl Barth has a Christocentric approach to the problem of theodicy. God chose eternally that He would live for us and we for Him. This union between Himself and man takes place through the incarnation of Jesus Christ. All God's works are done in order for Jesus Christ to exist (cf. Jenson, 1989:39).

Barth defines creation as the external basis of the covenant and the covenant as the inner basis of creation $(1958: 95,228)$. Creation provides the sphere in which the institution of the covenant take place, while the covenant is the goal of all God's works. The creation is the best possible world that God could create. God created the creation good. However, the remark in Genesis 1:31 that the creation was created good, is not a description of the cosmos as such, but must be seen in relation to Christ. The creation is good because it finds its goal and true meaning in Christ and the covenant 
(Barth, 1958:366-370). Because of Christ the created world is already perfect, despite its imperfection (Barth, 1958:384).

The creation was originally created free, and therefore had the possibility of self annulment and its own destruction. Without the possibility of defection or evil, creation would not be distinct from God and therefore not be his creation. A creature freed from the possibility of falling away would not really be living as a creature (Barth, 1957:503). Sin is when the creature opposes God and the meaning of its own existence by rejecting God's preserving grace. The fault is that of the creature and not of God or the nature of creation. The fact of evil does not cast any shadow on God because it does not find its origin either in God Himself or in His being and activity as the creator (Barth, 1957:504). God opposes the defection and destruction of the creature because He cannot cease to be God or cease to act as the Creator and Lord of the world and therefore also of the sinful world. His reply is rather to justify and maintain Himself in relation to the sinful world by resisting and overcoming sin (Barth, 1957:504, 505).

According to Barth (1957:594) evil, sin, wickedness, the devil, death and non-being exists in its own way by the will of God. Nothing exists outside of the will of God. He distinguishes between God's voluntas efficiens and voluntas permittens to explain the way in which evil exist by the will of God. God's voluntas efficiens is that what God positively affirms and creates, while his voluntas permittens consists in his refraining, non-preventing and non-excluding. God not only gives the creature its existence and being, freedom and independence (voluntas efficiens), but also refrains from making it impossible for man to misuse its independence and freedom (voluntas permittens). God creates in such a way that $\mathrm{He}$ also permits. The voluntas permittens is no less volunta divina than the voluntas efficiens, yet it is only a permission, a restricted toleration (Barth, 1957:595, 596). The question is: Why is God's will for creation not only a voluntas efficiens, a good will? Barth's precarious answer is that creation has to be constantly reminded of God's grace. God's grace depends on the existence of a divine voluntas permittens, and in virtue of this on the reality of disgrace, damnation and hell (Barth, 1957:595). Barth (1961:305) does not see good and evil dialectically, nor does he see them as two separate poles alongside each other, but he sees the whole of creation from the perspective of Christ (cf. also Louw, 2000:33). Since everything is created for Jesus Christ and his death and resurrection, everything 
from the very outset must stand under this twofold and contradictory determination (Barth, 1958:376).

Barth calls the reality that opposes and resists God's world dominion "nothingness". Nothingness is that from which God separates Himself and in face of which He asserts Himself and exerts his positive will (Barth, 1961:289, 351). The nature and being of nothingness consists in the fact that God has negated it in his grace and that it only exists in this relationship to grace. It does not exist in itself, but only in a state of anthithesis (Barth, 1961:332). Nothingness owes its existence to God in the sense that it is that which God has not willed and elected, but ignored, rejected, excluded and judged. It stands under God's no, the object of his jealousy, wrath and judgment (Barth, 1961:351). In this sense God is the author of nothingness. The first mention of nothingness in the Bible, according to Barth, is found at the beginning of creation in Genesis 1, where there is a reference to the chaos that God has rejected and negated even before He utters his first creative Word. Chaos is the unwilled and uncreated reality which constitutes as it were the periphery of his creation and creature. The first creative work of God is separation - separation of light from darkness, waters on the earth from waters of the firmament, and of dry land from the seas. Chaos is that which is distinct and excluded from God's works. Nothingness can be ascribed no other existence than in confrontation with God's not willing (Barth, 1961:353).

Sin is the concrete form of nothingness. It must be apprehended as the work of a powerful divine negation, as a reality that is not created but posited (Barth, 1961:326-328). Sin can never be understood positively, nor be esteemed, justified or established, because that which counterbalances grace and is indispensable to it is not real sin. Sin is rather the absence of good. It conforms to no law and is simply aberration and transgression (cf. Barth, 1961:333, 354). Yet nothingness is not exhausted in sin, because it is not only a moral category, but a total category that includes phenomena such as evil and death under which we suffer in connexion with sin. Evil and death can be distinguished from sin in that it directly attacks the creature and indirectly God, while sin attacks God directly and only indirectly the creature. Yet both attack creature and God (Barth, 1961:310, 311).

According to Barth (1961:309) Christ is the objective ground of knowledge of sin and nothingness. We can only know nothingness through our consciousness of God, because nothingness is that which God negates. Jesus Christ exposes nothingness through his 
work of justification. True nothingness is that which brought Jesus Christ to the cross, and that which He defeated there. In Christ nothingness is revealed in its entirety as the adversary than can destroy both body and soul, and as the evil power that invades and subjugates everything and stands in conflict with creature and creator (Barth, 1961:312). Because Christ reveals Himself to man in his opposition to real nothingness, man is confronted by the knowledge of nothingness as the opposition to good, and the truth that he is a sinner (Barth, 1961:306-308). At the same time we can see in Christ that God took to heart the attack on his creature, because $\mathrm{He}$ saw in it an attack on his own cause and therefore on Himself (Barth, 1961:304). Through Christ God makes the contradiction of human existence his own, and participates in the anthithesis of creation (Barth, 1958:380, 382).

Nothingness is not absolute, since it exists only through God, in the power of divine negation and the rejection of divine punishment. Its place is given by God, so that it is never over God, but always under Him. God's grace is mightier than sin evil and death (Barth, 1961:332). Grace is the basis of God's relationship with his creature, because having created the creature, God pledged his faithfullness to it (Barth, 1961:356).

By his suffering on the cross Christ takes away the power of death as the condemnation and destruction of the creature. The resurrection is the confirmation of his victory over sin, death and evil (Barth, 1961:312). Through Jesus Christ God and man meet as God in Jesus Christ and man in Jesus Christ. This eternal history is the principle and meaning of all else that happens (cf. Jenson, 1989:41). The victory of Christ's free grace is the achievement of the separation already recognisable in creation, and therefore as the destruction of chaos. In Christ nothingness and sin is finally destroyed. Through the cross God comes to us in action and Word, thereby identifying Himself with our suffering (cf. Louw, 2000:82).

The obedience of Christian faith exists in making a new beginning in remembrance of the One who has destroyed nothingness (Barth, $961: 355,365)$. Because of the living action of God in Christ, it is impossible for man to maintain an attitude of neutrality (Barth, 1958:387). However, the destruction of nothingness does not mean the end of all suffering. Until the second coming God still permits nothingness to retain its semblance of significance and manifest its already fragmentary existence, and man to be a prey of nothingness (Barth, 1961:367). 


\subsection{Evaluation}

Karl Barth makes an important contribution to the debate on theodicy by approaching the problem from the perspective of Christ. Since Christ is God's solution to suffering, any Christian debate on theodicy should start with Christ and the cross. Only in Christ is a positive theodicy possible. A natural approach to theodicy, that takes its premise in human experience, can not transcend the negative dimension of evil. However, Barth's approach creates certain problems:

- Barth's notion that God permits evil in order that Christ should exist, is problematic. The implication is that God willed evil (even if just in a permissive way) so that He can show us grace. This raises serious questions: is God's grace dependent on evil? If God permits sin, how can He judge sin? (cf. König, 2002:96). If God permits evil, how can He be a loving God? Apart from the fact that this hypothesis endangers the moral perfectness of God, Scripture does not speak of God's grace in this way. God's grace is not presented in Scripture in objectivist categories, but is seen as God's answer to suffering and evil. Barth's theology tends to degenerate into determinism, because of his predestinarian approach.

- Barth's notion that nothingness finds its origin in the seperative creational acts of God is not based on sound exegesis. His understanding of the words בהו תהו in Genesis 1:2 as primordial chaos is based on tendential exegesis. These words simply refer to deep waters. It does not represent that which is hostile to God, but rather serves as an image of the formlessness and lifelessness which precede the divine act of creation, without any tangible or objective quality (cf. Eichrodt, 1967:105; Harris, Archer \& Waltke, 1980:2496). By relating nothingness (evil, sin and death) to the imperfect side (structure) of the original creation that find its perfection only in the prospect of the coming of Christ, Barth separates the problem of theodicy to such a degree from the fall that he depersonalises evil. Evil and sin is the absence of good that belongs to the structure of creation, a negative power that is being rejected by God. Scripture in contrast speaks of evil in personal and existensial terms (cf. Gen. 3; Jam. 2:14, 15; Rom. 3; Matt. 4:1-12, et cetera). Because of this depersonalisation of evil, the love of God dominates in Barth's theology the righteousness and vengeance of God which calls man to account because of his personal guilt (cf. also Berkouwer, 1950:316-318). 
- Barth's hypothesis that creation had to be created free with the possibility of self annulment and imperfection, so that the creation can be distinct from God, has problematic consequences for Christian eschatology. If a free human will is a precondition for true creatureliness, the question is: Is the same argument not valid for the new creation? If so, what quarantee is there that a second fall will not occur? Other questions also arise: Is freedom to sin really freedom? Does it not make God co-responsible for sin? Does true human freedom imply that God must limit His own power? (cf. König, 2002:204-206.)

\section{Jürgen Moltmann}

\subsection{Eschatological theodicy}

The problem of theodicy lies at the heart of Moltmann's theology. From the beginning he gave prominence to the question of God's righteousness in the face of suffering and evil in the world (cf. Bauckham, 1989:300). In Theology of hope Moltmann proposes an eschatological theodicy. He places emphasis on the resurrection and eschatology as Realgrund for Christology. The resurrection become the key to, and the exegesis of the cross (cf. Moltmann, 1974:162; Louw, 2000:82, 83). The resurrection qualifies the cross as an eschatological saving event (Moltmann, 1974:182). This means that history must be outlined from the perspective of eschaton. The parousia of God and of Christ opens the way for time and sets history in motion through expectation and promise (Moltmann, 1967:31, 58). The task of Christian eschatology is to formulate its statements of hope in contradiction to our present experience of suffering, evil and death (Moltmann, 1967:19). Suffering, death and evil must not be justified as part of the divine purpose, nor accepted as part of reality. The resurrection is God's contradiction of suffering and death and the protest of the divine promise against suffering. It sets in motion an eschatologically determined process of history, whose goal is the annihilation of death and the victory of the life of resurrection, ending in righteousness and salvation. The resurrection provides hope for God's final triumph over evil and suffering, because it discloses an eschatological future (cf. Moltmann, 1967:21, 163, 181). This hope empowers Chrisians to liberate and transform reality and overcome suffering through Christian praxis and mission (Moltmann, 1967:34).

The Christian hope is based on promise. Gods revelation is nothing else than promise. Through the covenant man participates in the promises of God. Promise announces the coming of a not yet 
existing reality from the future of truth. However, the truth of God's promises can only be verified in the future. Future is the reality which fulfill and satifies the promise. It does not have to develop within the framework of the possibilities inherent in the present, but arises from that which is possible to the God of promise. Thus the believer becomes essentially one who hopes, who lives between the contradiction of the present and future (Moltmann, 1967:86-103, 172). The hope that is born on the cross and the resurrection transforms the negative, contradictory and torturing aspects of the world into terms of "not yet", and not "nothing" (Moltmann, 1967: 197).

The future becomes present in Christ who proclaims the breaking in of the future in the present (Moltmann, 1967:139). The relation between the cross and resurrection is dialectical in nature and will find its synthesis only in the eschaton of all things. Cross and resurrection stand in the same relationship to each other as death and eternal life. The cross represents the reality subject to sin, suffering and death, while the resurrection represents the new reality that will reflect the glory of God. The cross provides the historical basis and actuality for the resurrection, while the resurrection provides the meaning dimension of salvation (Moltmann, 1967:200, 201, 226; cf. Bauckham, 1989:301; Louw, 2000:84). Therefore, in a theology of the cross, hope can not be reduced to a mere principle, but it is a Person (cf. Louw, 2000:84).

In The crucified God (1974) and The way of Jesus Christ (1990), Moltmann deepens his approach to the problem of theodicy in terms of hope for God's future, with the additional theme of God's loving solidarity with the world in its suffering (cf. Bauckham, 1989:300). He places the dialectic event of the cross and resurrection within God's own trinitarian experience. The cross is a dialectical event of suffering in the trinity itself. It stands at the heart of the trinitarian being of God, because it divides and conjoins the persons in their relationships to each other (Moltmann, 1974:206, 244). The Son suffers by dying in godforsakenness, being abandoned by his Father, while the Father suffers the grief of the death of a Son. The surrender of the Father and Son is made through the Spirit who is the bond in the division. The sufferings of Christ are also the sufferings of the Spirit, for the surrender of Christ is manifested in the self-emptying of the Spirit (Moltmann, 1990:173-174; 1974:92, 243). Moltmann's dialectical construction of the trinitarian dialectic is based on the Hegelian view of history as a development from thesis and anthithesis to synthesis: the Father forsakes the Son (thesis), 
the Son experiences forsakenness (anthithesis), God identifies with our suffering (synthesis) (cf. Louw, 2000:91).

According to Moltmann, the message of the cross is that God and suffering are not contradictions, but God's being is being in suffering and suffering is in the being of God, because God is love and love exposes one to suffering (Moltmann, 1974:227, 230). In this way God suffers in solidarity with those who suffer, and embraces the godforsaken reality by giving Himself for us (Moltmann, 1974:46-47). This is love which meets the involuntary suffering of the godforsaken with another kind of suffering: voluntary fellow suffering (cf. Bauckham, 1989:300). The cross does not solve the problem of suffering, but awakens hope for a new world, by meeting suffering with voluntary selfsuffering, thereby bringing fellowship to lost beings (Moltmann, 1990:175, 178, 193). In one's own pain, we discover the pain of God, creating fellowship with God in one's own suffering, and overcoming the suffering in suffering (Moltmann, 1974:56; 1990: $180)$. In this way human history is taken up in the history of God, because there is no suffering in the history which is not God's suffering (Moltmann, 1974:246).

Moltmann never isolates the suffering on the cross from the victory of resurrection, because hope is essentially the hope of the resurrection (cf. Louw, 2000:85). With Christ's resurrection an universal theodicy trial begins which can only be eschatologically completed with the resurrection of all the dead and the annihilation of death's power. Then the pain of the theodicy question will be transformed into the universal cosmic doxology (Moltmann, 1990:183). Faith in resurrection answers the theodicy question through justification. It is not the nomos that will eventually give every person his deserts, but the law of God's grace. The message of the new righteousness that eschatological faith brings into the world, says that the executioners will not triumph over their victims, nor will the victims triumph over their executioners. Christ who died for both victims and executioners will triumph by revealing a new righteousness which will break through the vicious circles of hate (Moltmann, 1974:178). The faith that springs from the intertrinitarian event on the cross does not give a theïstic answer to the question of suffering, but enters the history of God who suffers with us and in us (Moltmann, 1974:253, 254).

\subsection{Evaluation}

The value of Moltmann's eschatologia crucis, is that he addresses the inadequacy of a theistic approach to the problem of theodicy. The question of God's righteousness amidst suffering cannot be 
solved by rational methaphysical abstractions of the being of God. Such an approach leads to further inconsistencies. God answers the problem of suffering through the event of the cross. The cross is a clear sign that suffering must not be justified and should not be seen as part of the divine purpose. By seeing God's suffering on the cross as the point of departure for Christian theology, Moltmann emphasises the solidarity of God with suffering, thereby removing abstraction from the debate and bringing pastoral comfort to those who suffer. His emphasis on the resurrection and eschatology as the key to interpret the events on the cross, and as ground for the Christian hope amidst suffering, places the concept of the suffering God within the ongoing narrative of God's redemption of creation, thereby bringing a liberating and missionary dimension to the debate on theodicy.

Moltmann's eschatological theodicy provides a possible paradigm to approach theodicy, but it also contains certain weaknesses:

- Though the Trinitarian God certainly suffered in some way or another in the event of the cross, Moltmann's reliance on Hegel's dialectical method brings an element of speculation into his doctrine of the trinity (cf. Louw, 2000:91). The question is: Is Moltmann not enforcing the philosophy of Western idealism on the events of the cross and the intertrinitarian relationship of God? Does this view really represent Scripture's salvic understanding of the events of the cross?

- Moltmann's theology is, furthermore, in danger of elevating suffering to the constitutive and unifying element of Gods being, thereby obscuring and dominating other ways in which the triune God operates. Though suffering is an element in the interaction of the Trinitarian being, it must not be seen as the constitutive element of the Trinitarian being.

- Moltmann's view that human history is part of God's history has a panentheistic sound to it. His concept of the suffering God relates God and man to such a degree, that he is in danger of negating the total otherness of God. God's sovereignty can easily be sacrificed by a overemphasis on God's incarnation and identification (cf. Louw, 2000:42). Moreover, he states God's solidarity with suffering in such comprehensive and absolute terms that his theology tends to embrace a doctrine of universal reconciliation that is not Scripturally founded (cf. Rom. 9). 


\section{The hermenetical challenge to Christianity}

The problem of theodicy is important in the sense that it poses a hermeneutical challenge to Christianity. The challenge is not only to find an answer, but to decide the grounds on which the question of evil and suffering is properly to be asked. Theology, in my view, needs to answer three basic hermeneutical questions with regard to the problem of theodicy, namely: Can theology reconcile itself with the Leibnizian formulation of the problem of theodicy? What is the boundaries of theology? Does the classical Christian concept of the omnipotence of God, as infinite power, have a sound Biblical basis?

\subsection{The historical origin of theodicy}

The question of theodicy finds its origins in the Enlightenment. The Enlightenment philosopher, G.W. Leibniz, was the first to pose the theodicy question in its modern form. In contrast to preEnlightenment theology who saw the problem of suffering as a practical problem, atheism and theism used the methods of the Enlightenment that replaced the authority of Scripture, faith and tradition with the authority of the autonomous individual's pure reason that only accepts those propositions that can be accepted by all rational beings. Atheism and theism approached theodicy in a profoundly theoretical way. Though the conclusions of atheism and theism differs, the method is essentially the same. Both quest for logical, cognitive, a-historical answers to the problem. The failure of theism lies therein that it subjected the Christian religion to the Enlightenment, by separating the debate on theodicy from faith and revelation, seeking to justify God by using rational methaphysical arguments. By subjecting Christianity to the rationalist methods of the Enlightenment, theism actually contributed to the secularisation of society. Berkouwer $(1950: 277,299)$ rightly asks whether human reason can justify God. The falsity of the theodicy question, as formulated with the Enlightenment, consists therein that it approaches the problem of evil and suffering from the perspective of human experience. Experience can, however, not provide any consistent answers with regard to theodicy.

\subsection{The boundaries of theology}

The fundamental epistemological question that arises from the debate on theodicy is: What is the boundaries of theology? Is all theological questions legitimate or are certain questions beyond the scope of theological enterprise? Theology can certainly be nothing else than the study of God's selfrevelation. Without a God that 
reveals himself, there can be no true theology, since God cannot be known if he does not reveal Himself. The concept of God is simply beyond the scope of empiric scientific study and philosophical rationalism.

The abovementioned definition of theology necessarily implies two things. Firstly, theological inquiry are a faith oriented discipline based on the belief that the Scripture contains God's selfrevelation. Secondly, theology are subjected to certain boundaries. It can only enquire and theorise about that which is revealed, and not that which is not revealed. Questions about the "not revealed" can be nothing more than philosophic speculation. Scripture does not seek to answer all existensial questions, nor to provide a complete explanation of God's being and works. It rather aims to bring the human being in a relationship with God.

It may well then be asked whether this does not mean that theology take refuge in irrationalism, as soon as it find difficulty to answer certain questions? Is it not the task of theology to investigate the anomalies in God's selfrevelation and to critically evaluate the truth claims of Scripture? If the Christian faith claims to posess the truth, shouldn't it be willing to subject all its claims to rational enquiry? The problem with these sort of questions is that they are based on a rationalist view of reality. All human knowledge are preliminary and to a certain extent faith-based. Most scientific disciplines is continually confronted by anomalies and rational inconsistencies that cannot be explained. The fact that we can't explain all phenomena that we encounter, does not mean that those phenomena does not exist.

Theistic speculation on the problem only leads to logical contradictions. There is no logical solution to the problem. Theology must accept the origin of evil as a mystery that cannot be explained, in the same way as it accepts the trinitarian existence of God and the two natures of Christ as divine mysteries that cannot be logically or rationally explained in all its dimensions. Mystery is an undeniable feature of the Christian religion. In the Old Testament the mysterious nature of God's ways are repeatedly emphasised (cf. Is. 45:15; Exod. 3:14).

The important theological question, therefore, is not what the origin of suffering is, but what God's solution for the problem of suffering is. In this regard the theology of the cross makes an important contribution to the debate. The cross and resurrection is God's answer to suffering. It is a sign that suffering is not part of God's 
purpose, and at the same time an affirmation that God has conquered the forces of evil and suffering. Ultimately a Christian theodicy must be eschatological. Instead of looking to the past for the mystery of evil, it ought to look at the ultimate future to which only faith can look (cf. Hick, 2003:77).

Christian theology can only approach suffering in the way that Scripture itself approaches the problem. Scripture does not give a systematic theoretical view of suffering, but it approaches the problem from a pastoral existensial point of view. The question in Scripture is not whether suffering contradicts the existence of a God, but how does God relate to human suffering?

The whole question of theodicy became important in Israel in the 6th and 7th century before Christ, after the collapse of Jerusalem, the temple and the dynasty. Yet the question on the meaning of suffering did not so much arise out of the experience of suffering, but against the background of Israel's faith in a God that made a covenant with her, and promised her glory. The loss of Israel's control over her political destiny, called into question the deuteronomic and sapiental theories that good people prosper and evil people suffer. It is against this background that literature such as the book of Job developed, probing the question of God's justice (Hauerwas, 1989:43). The book of Job is a protest against the view of God as a logical mechanical God whose actions is determined by cause and effect. In Job, three of Job's friends, represent the earlier deuteronomic and sapiental view, and is severly reprimanded at the end of the book for their foolishness. The writer of Job rejects all logical, theoretical answers on the origin of evil, but rather emphasises the faithfulness of God amidst suffering, even though the sufferer does not understand the reason for his suffering (cf. Louw, 1982:31). In the lament psalms God is often confronted, in a similar vein as in Job, by sufferers. Yet, according to Bruegemann $(1977: 266)$ the lament emerges from basic trust, rather than from brute anger. It is not an indication of distrust in God's faithfulness, but rather an expression of profound trust and expectation that God will deliver.

In the New Testament suffering is not seen as a theoretical methaphysical problem, but as an existensial practical problem (cf. Hauerwas, 1989:85). The goodness of God amidst unjust suffering is never questioned, but suffering is seen as a practical challenge to faith that can only be endured and responded to in faith through the power of the Holy Spirit (cf. Rom. 8). Suffering, even unjust suffering, is seen as an opportunity to grow in faith (1 Pet. 
$1: 6,3: 13,14$; Jam. 1:3). Faith does not question the existence of God amidst suffering, but seeks to find God amidst suffering. Though it is true that the unjust persecution of the early Christians gave a special meaning and telos to their suffering, their approach to suffering was determined by their identification with the suffering Christ. It was Christ's unjust suffering that gave meaning to their own unjust suffering (cf. 1 Pet. 4:3). For modern Christians too no suffering can be meaningless, because all suffering has Christ as its telos. Christ, indeed, brings a new dimension to all forms of suffering.

\subsection{The omnipotence of God}

God's omnipotence has traditionally been understood as the absolute, all-conquering and infinite power of God. Without this power God will not be God (Van de Beek, 1990:6). However, if the omnipotence of God is understood as infinite power, then no one can be satisfied with an answer that is less than the abolition of suffering as such (cf. Hauerwas, 1989:48). The theistic concept of God as an all-powerful, perfect and infinite being, is not derived from Scripture itself but rather has its historical origin in the God images of the Hellenistic (pantokrator) and Roman era (despotes) (cf. Moltmann, 1974:250; Louw, 2000:43; König, 2002:208-210). According to Louw (2000:47) it is an open question whether omnipotence should be viewed as an essential description and accurate attribute of God telling us something of his being. It is rather a metaphor portraying God's unique faithfulness and steadfastness in relation to his covenant people. The term Almighty, שד 'ש is not used often in the Old Testament. It's meaning is not clear and can only be determined by the contexts in which it is used (cf. Louw, 2000:52). The term omnipotence does not occur in the New Testament, except in passages that quotes the Old Testament. In these passages the word (pantokrator) is used. It is, however, doubtfull whether this translation is a true expression of the meaning of שד' because the meaning of שד' שר is not clear (cf. König, 2002:210). The Old Testament usually talks about the sovereignty and omnipotence of God within the context of God's superiority over all other gods (Jer. 32:18), God as the true God (1 Sam. 17:26), the faithful Saviour of his people (Gen. 17:8, Job 13:3), God as Judge (Ps. 50:6), the righteousness and justice of God (Ps. 4:1), God's actions on behalf of his people (Deut. 5:23) and God's intimacy with his people (Jer. 23:23; Harris, Arcer \& Waltke, 1980:41-45). God's omnipotence can therefore not be understood as a negative destructive power in the Hellenistic and Roman sense, but it is the overwhelming power of 
God's love. Omnipotence describes a power which is closely connected with God's covenantal encounter and graceful identification with our human misery. The sovereignty of God does not mean that He controls everything in a mechanical and deistic way, but that He empowers us through his grace and love (Louw, 2000:54; König, 2002:209).

\section{Conclusion}

In the introduction to this article it was stated that protest atheism is mainly a negative response to the question of theodicy. The question is: What should the Christian response to protest atheism be? The conclusion of this article is that theoretical attempts to justify God logically cannot create hope, because it will only create new cognitive inconsistencies. The Christian approach should rather be determined by kerugma, since it is the universal existensial longing for meaning amidst pain that provides an opening for the Christian message. Pain can only have meaning, if there is a God. Without God pain has no meaning. We can only endure pain, if we live with the eschatological hope that this world is not our final destination. The Christian response to protest atheism should not focus on the why of evil, but on God's victory over evil and suffering, by preaching the historical event of the cross and resurrection, and the coming of God's parousia that creates hope amidst suffering.

\section{List of references}

BARTH, K. 1957. The doctrine of God: church dogmatics. Vol. 2(1). Edinburgh: Clark.

BARTH, K. 1958. The doctrine of creation: church dogmatics. Vol. 3(1). Edinburgh: Clark.

BARTH, K. 1961. The doctrine of creation: church dogmatics. Vol. 3(3). Edinburgh: Clark.

BAUCKHAM, R. 1989. Jürgen Moltmann. (In Ford, D.F. The modern theologians: an introduction to Christian theology in the twentieth century. Vol. 1. Oxford: Blackwell. p. 293-311.)

BERKOUWER, G.C. 1950. De voorzienigheid Gods: dogmatische studien. Kampen: Kok.

BRUEGEMANN, W. 1977. The formfulness of grief. Interpretation, 31:263-275.

EICHRODT, W. 1967. Theology of the Old Testament. Transl. from the German by John Baker. London: SCM.

HARRIS, R.D., ARCHER, G.L. \& WALTKE, B.K. 1980. Theological wordbook of the Old Testament. Vol. 2. Chicago: Moody Press.

HAUERWAS, S. 1989. Naming the silences: God, medicine and the problem of suffering. Grand Rapids: Eerdmans.

HICK, J. 2003. Evil and the God of love. (In Astley, J., Brown, D. \& Loades, A. Problems in theology. Vol. 2: Evil. London: Clark. p. 76-78.) 
JENSON, R.W. 1989. Karl Barth. (In Ford, D.F. The modern theologians: an introduction to Christian theology in the twentieth century. Vol. 1. Oxford: Blackwell. p. 23-50.)

KÖNIG, A. 2002. God, waarom lyk die wêreld so? Kan ons sê: "God is in beheer". Wellington: Lux Verbi.BM.

LOUW, D.J. 1982. Job 33:23-30. (In Burger, C.W., Müller, B.A. \& Smit, D.J., reds. Riglyne vir lydensprediking. Kaapstad: NG Kerk Uitgewers. p. 3037.)

LOUW, D.J. 2000. Meaning in suffering: a theological reflection on the cross and the resurrection for pastoral care and counselling. New York: Peter Lang.

MOLTMANN, J. 1967. Theology of hope. Translated from the German by J.W. Leitsch. London: SCM.

MOLTMANN, J. 1974. The crucified God. Translated from the German by R.A. Wilson \& J. Bowden. London: SCM.

MOLTMANN, J. 1990. The way of Jesus Christ: Christology in messianic dimensions. Translated from the German by M. Kohl. London: SCM.

VAN DE BEEK, B. 1990. Why? On suffering, guilt and God. Grand Rapids: Eerdmans.

\section{Key concepts:}

Barth

Moltmann

suffering

theodicy

\section{Kernbegrippe:}

Barth

lyding

Moltmann

teodisee 
